\title{
Genetic Diversity Study Among Six Genera of Amaranth Family Found in Malang Based on RAPD Marker
}

\author{
Arik Arubil Fatinah ${ }^{1}$, Estri Laras Arumingtyas ${ }^{1 *}$, and Retno Mastuti ${ }^{1}$ \\ ${ }^{1}$ Departement of Biology, Faculty of Mathematic and Natural Sciences, Brawijaya University, Malang
}

\begin{abstract}
Genera of amaranth family tend to have phenotypic variation partly caused by environmental factor. Phenotypic variation was the result of interaction between genetic and environmental factors. One of molecular markers that is widely used for detecting genetic variation is RAPD. RAPD is used for polymorphism detections and is now possible for identifiying a large number of loci and ascribes unambiguous taxonomic and genetic relationships among different taxa. Members of amaranth family found in Indonesia are Amaranthus, Celosia, Aerva, Alternanthera, Achyranthes, Gomphrena, Salsola, and Iresine. Six genera of which (Amaranthus, Celosia, Aerva, Alternanthera, Achyranthes, and Gomphrena) were observed in this study. DNA was extracted from fresh young leaves using Doyle and Doyle's method with modification in the extraction buffer used. RAPD analyses were carried out with 20 decamer primers from Kit A of Operon Technology. DNA was amplified using master cycler gradient Eppendorf with 35 cycles. RAPD products were separated on 1,5\% agarose gels and detected by staining with ethidium bromide. There were 374 bands generated in 18 random primers. The number of monomorphic bands, polymorphic bands, and the percentage of polymorphism were 21 bands, 353 bands, and 94,38\% respectively. The high number and percentage of polymorphic bands revealed genomic DNA variation. This variation is in accordance with phenotypic variation detected in this experiment. Therefore, it can be concluded that, based on DNA polymorphism detected by RAPD, Amaranth family can be classified into two sub families namely Amaranthoideae and Gomphrenoideae.
\end{abstract}

Keywords: Amaranth family, RAPD.

\section{INTRODUCTION}

Amaranthaceae (Amaranth family) is a core family of Caryophillalales Order. This family consists of 169 genera and 2360 species. This family is widely dispersed in temperate and tropical zone [1,2]. Genera of Amaranthaceae tend to have phenotypic variation partly caused by environmental factors [3]. The phylogeny developed based on morphological features has limitation in data accuracy because of high subjectivity [4]. Random amplified DNA polymorphic (RAPD) is one of the molecular markers that can be used in the study of phylogeny. RAPD is used for polymorphism detection, and it is now possible to survey a large number of loci and ascribes unambiguous taxonomic and genetic relationships among different taxa $[5,6]$.

\footnotetext{
*Corresponding address: Estri Laras Arumingtyas

Biology Department, Faculty of Math. and Natural Sciences, Brawijaya University, Jl. Veteran, Malang, Indonesia 65145 Email: laras@ub.ac.id
}

Members of Amaranthaceae found in Indonesia are Amaranthus, Celosia, Aerva, Alternanthera, Achyranthes, Gomphrena, Salsola, and Iresine [7]. Six genera of which (Amaranthus, Celosia, Aerva, Alternanthera, Achyranthes, and Gomphrena) were observed in this study. The members of Amaranth family have been acknowledged as future food, and they have high potential as a medicinal plant. Amaranth family has a high nutritional value and produces betalain as colorant [8]. Betalain is a phytochemical marker for Amaranthaceae $[9,10]$. Betalain produced by amaranth family is named as betacyanin. The betacyanin is further divided into four sub-groups: betanin group, amaranthine group, gomphrenin group, and 2descarboxy-betanin group [11]. From the betacyanin sub-group, amaranth family is divided into two sub-groups, amaranthine and gomphrenin groups. The data showed that amaranth family comprised two groups: amaranthoideae and gomphrenoideae. Phylogenetic study of Amaranth family is used 
for finding an alternative plant that produces high level of betalain. This colorant is widely used as antifungal, anti-malarial, and antiviral. Beside that, this colorant can be used as healthy food colorant [11].

\section{MATERIALS AND METHODS}

\section{Plant Material}

Six plants of amaranth family, Amaranthus sp., Alternanthera sp., Aerva sp., Celosia sp., Achyranthes sp., and Gomphrena sp were used in this study. All of these plants were collected from wild habitat in Malang, East Java.

\section{Morphological Analysis}

The study used 31 morphological features for identification. The morphological features were based on identification books (Flora of Java, Flora of Malesiana, and Morfologi Tumbuban).

\section{DNA Extraction}

The DNA genome was extracted from fresh young leaves using Doyle and Doyle's method [1], which was modified in CTAB extraction buffer. As much as 0,1 gram fresh young leave was grinded using mortar and pestle, and then was added with $1 \mathrm{ml}$ extraction buffer. The extraction buffer consists of $2 \%$ CTAB; $0,1 \mathrm{M}$ Tris-HCl; 3,5 M NaCl; $20 \mathrm{mM} \mathrm{Na} 2$ EDTA; $2 \%$ PVP; and $2 \% \beta$-mercaptoethanol.

\section{DNA Amplification using RAPD}

RAPD analyses were carried out using 20 decamer primers from Kit A of Operon Technology (Table 1). RAPD reaction was prepared with mixture of $5 \mu$ PCR master mix $2 \mathrm{x}$ solutions from Intron Biotechnology, $2 \mu \mathrm{l}$ OPA primers $(10 \mathrm{pmol}), 2 \mu \mathrm{l} d d \mathrm{H}_{2} \mathrm{O}$, and $1 \mu \mathrm{l}$ DNA (100-250 ng/ $\mu \mathrm{l})$. DNA was amplified using Master Cycler Gradient Eppendorf. The RAPD program started with 5 min of $95^{\circ} \mathrm{C}$ incubation, followed by 35 cycles of $1 \mathrm{~min}$ at $95{ }^{\circ} \mathrm{C}$ denaturing, $1 \mathrm{~min}$ at $36{ }^{\circ} \mathrm{C}$ annealing, and $2 \mathrm{~min}$ at $72{ }^{\circ} \mathrm{C}$ extension. The reaction finished with 5 min at $72{ }^{\circ} \mathrm{C}$ incubation and stopped at $4{ }^{\circ} \mathrm{C}[13]$. RAPD products were separated on $1,5 \%$ agarose gels and were detected by staining with ethidium bromide.

\section{Data Analyses}

Bands of equal molecular weight and mobility generated by similar primer were considered to be identical locus. Genetic and morphological similarities between six genera were measured using similarity index [14], and were used to constract a dendogram using UPGMA (Unweighted pair group method with arithmetic average). All the statistical analyses were carried out using the NTSYSpc 2.1 version (Exeter Software, Setauket, N. Y.) software package [15].

Table 1. Primer used in RAPD amplification

\begin{tabular}{lll}
\hline No. & Primers & Sequences \\
\hline 1. & OPA1 & CAGGCCCTC \\
2. & OPA2 & TGCCGAGCTG \\
3. & OPA3 & AGTCAGCCAC \\
4. & OPA4 & AATCGGGCTG \\
5. & OPA5 & AGGGGTCTTG \\
6. & OPA6 & GGTCCCTGAC \\
7. & OPA7 & GAAACGGGTG \\
8. & OPA8 & GTGACGTAGG \\
9. & OPA9 & GGGTAACGCC \\
10. & OPA10 & GTGATCGCAG \\
11. & OPA11 & CAATCGCCGT \\
12. & OPA12 & TCGGCGATAG \\
13. & OPA13 & CAGCACCCAC \\
14. & OPA14 & TCTGTGCTGG \\
15. & OPA15 & TTCCGAACCC \\
16. & OPA16 & AGCCAGCGAA \\
17. & OPA17 & GACCGCTTGT \\
18. & OPA18 & AGGTGACCGT \\
19. & OPA19 & CAAACGTCGG \\
20. & OPA20 & GTTGCGATCC \\
\hline
\end{tabular}

\section{RESULT AND DISCUSSION}

\section{Phylogeny of Amaranthaceae Based on Morphological Features}

As many as 31 characters were used for the morphological analysis (data not shown). All of the characters were conferred into character states. Character states data were converted to binary digits that formed the source of data for phylogenetic analysis. The phylogenetic tree based on UPGMA analysis of the morphological data comprising 31 character states indicated a similarity between all the 6 genera at the $57 \%$ level (Figure 1). Nevertheless, it was interesting to note that there were two sub-branches that suggested two sub-families of amaranth family.

The first sub-branch consisted of Amaranthus and Celosia with $63 \%$ degree of similarity. The second sub-branch consisted of Aerva, Alternanthera, Achyranthes, and Gomphrena; four of them had 73,5\% degree of similarity. Both subbranches had the same characters, and called sinapomorphy characters. Sinapomorphy characters for both sub-branches were stem erect, monopodial branching, basal leaves acuminate, perianthium present, ovary superior, utricle fruit, shiny black seed, and betalain present. Morphological data had limitations; however, the morphological analysis was very 
useful for field analysis. The morphological analysis established in plant phylogeny.

\section{Phylogeny of Amaranthaceae based on Molecular data}

The number of DNA bands were varied, depending on the primer used (Figure 2). From
18 primers used in this experiment only OPA3, OPA4, OPA4, OPA6, OPA7, OPA8, OPA9, OPA10, OPA11, OPA12, OPA13, OPA14, OPA15, OPA16, OPA17, OPA18, OPA19 and OPA20 which were capable of amplifying the DNA genome.

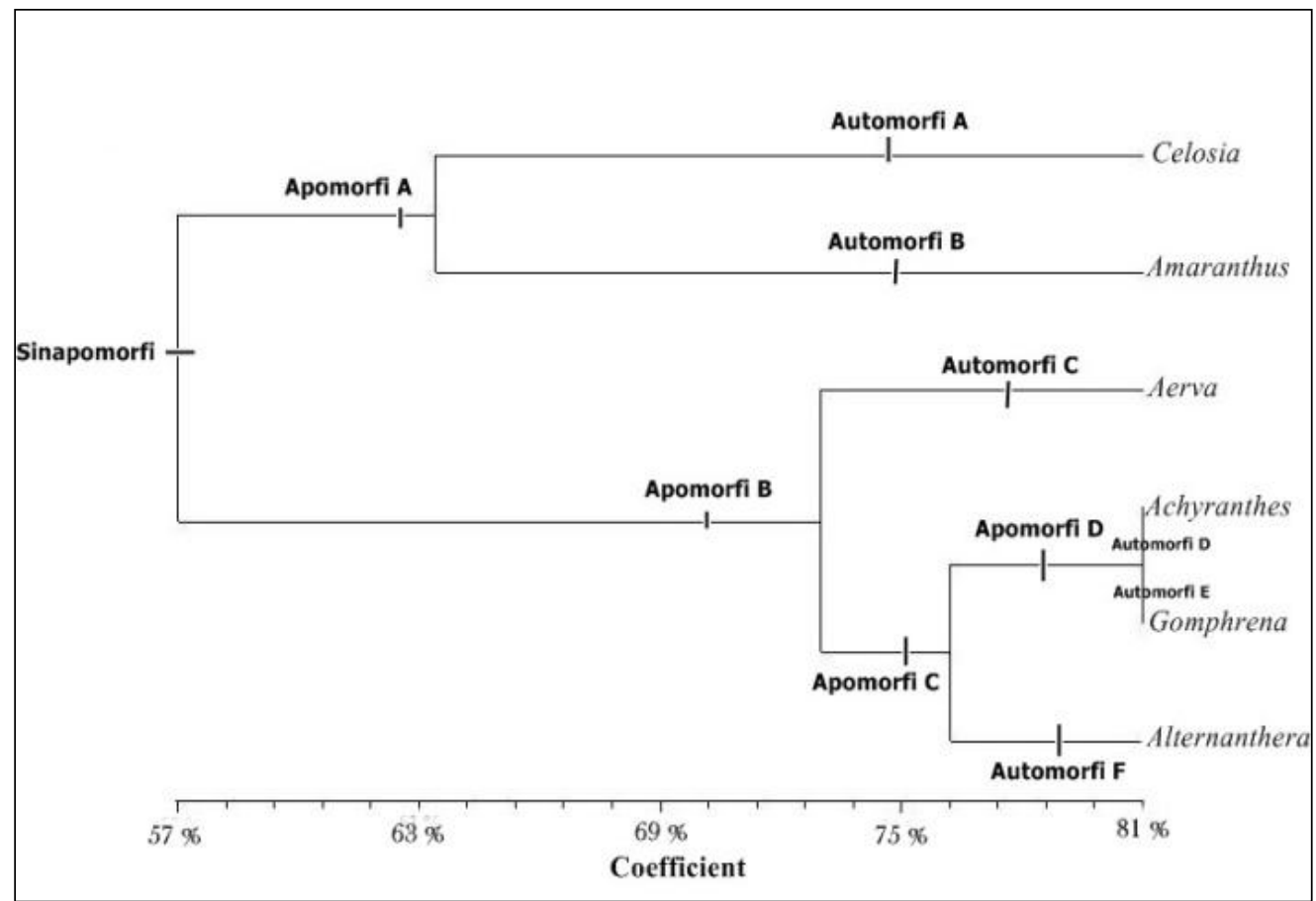

Figure 1. Phylogeny of Amaranthaceae based on morphological features and analyses using UPGMA

For the phylogenetic analysis, 374 bands were generated by those 18 primers. An equal weight and mobility of band generated by the same primer were considered to be the same locus and had the same value. The data converted to binary digits that formed the source of data for the phylogenetic analysis. The phylogenetic tree based on UPGMA analysis of the RAPD data comprising 374 bands indicated a similarity between all the 6 genera at the 50\% level (Figure 3). The first sub-branch consisted of Acbyranthes, Aerva, and Alternanthera, with $56 \%$ degree of similarity. The second sub-branch consisted of Amaranthus, Celosia, and Gomphrena, with 52,5\% degree of similarity. DNA bands generated from RAPD had high genetic diversity, and supported with high percentage of polymorphism (94,38 \%) (Table 2).
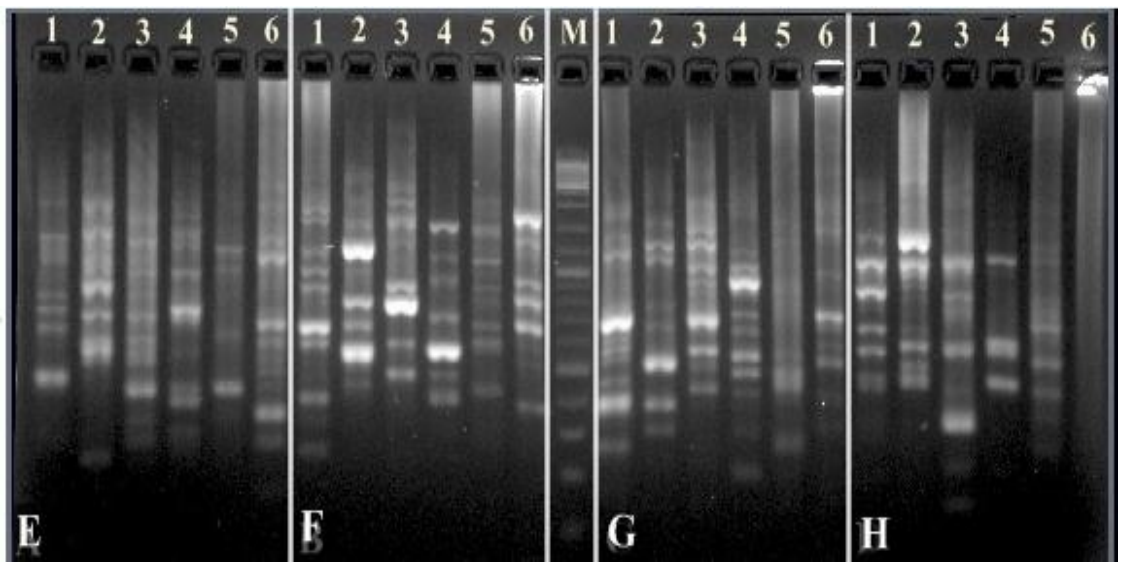

Figure 2a. Electrophoregram RAPD fragments, $\mathrm{E}=\mathrm{OPA} 5 ; \mathrm{F}=\mathrm{OPA} 6 ; \mathrm{G}=\mathrm{OPA} 7 ; \mathrm{H}=\mathrm{OPA} 8 ; 1=$ Achyrantes; 2=Aerva; $3=$ Alternanthera; $4=$ Amaranthus; $5=$ Celosia; $6=$ Gomphrena; $M=$ marker 


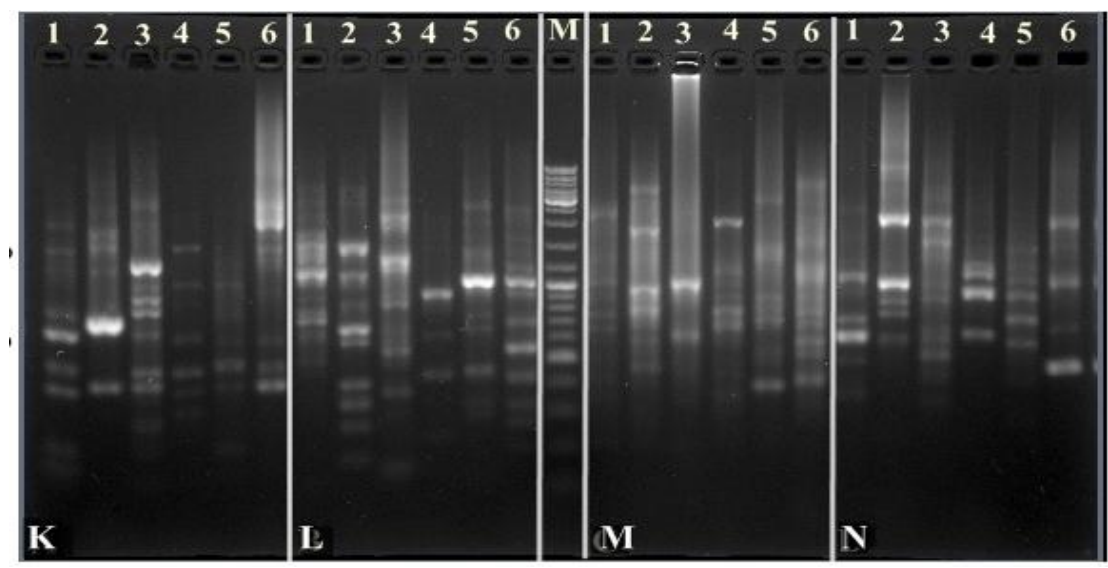

Figure 2b. Electrophoregram RAPD fragments, $\mathrm{O}=\mathrm{OPA} 15 ; \mathrm{P}=\mathrm{OPA} 16 ; \mathrm{Q}=\mathrm{OPA} 17 ; \mathrm{R}=\mathrm{OPA} 18 ; 1=$ Achyrantes; $2=$ Aerva; $3=$ Alternanthera; $4=$ Amaranthus; $5=$ Celosia; $6=$ Gomphrena; $\mathrm{M}=$ marker

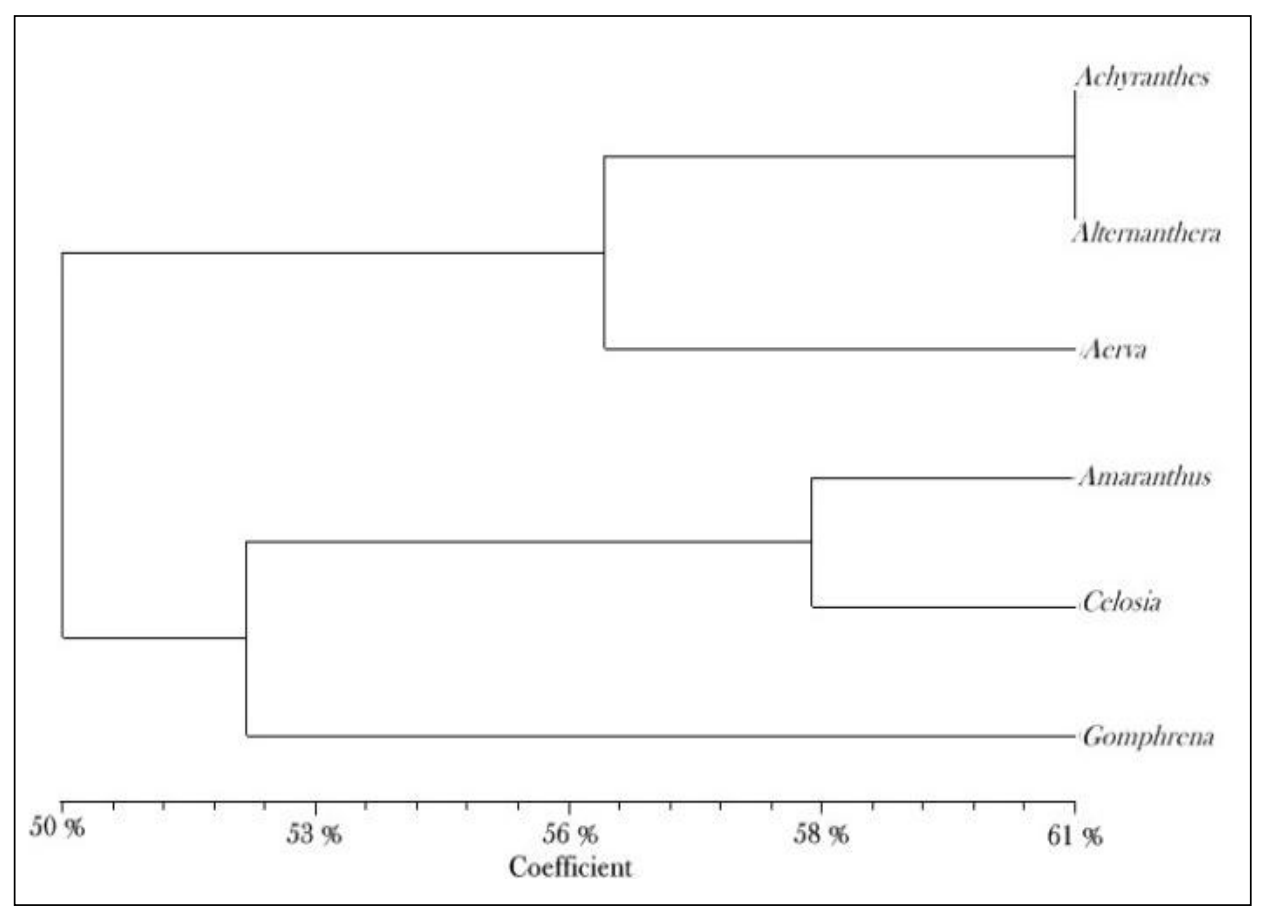

Figure 3. Phylogeny of Amaranthaceae based on molecular data using UPGMA

Dendogram that was generated from molecular data had different topology profiles from the ones in the morphological data. Dendogram from the molecular analysis showed that Gomphrena was included in Amaranthoide clade. Classifying Gomphrena to Amaranthoide clade was caused by a non-separating band in this sample. Non-separating bands are especially caused by incompatibility of primer to amplify DNA genome.

The molecular data suggested that there were two sub-families in Amaranthaceae. The members of genera in each subfamily were different from the results of the morphological analysis. It is then suggested that the analysis be conducted using different marker, especially using cpDNA region. Members of amaranth family have variation on morphological characters. That variation is a result of high genetic diversity, differences of growing type, and differences on the type of adaptation [16,17]. Morphological analysis has limited especially because of high subjectivity and because it cannot determine taxa up to their species level. Molecular markers can be used for phylogenetic analysis and can determine up to infraspesific level. Molecular markers have high objectivity.

Based on the morphological variation, the amaranth family was divided into two subfamilies. The first sub-family, namely Gomphrenoideae, had 2-locular anthers, and the second sub-families, namely Amaranthoideae, had 4-locular anthers and four tribes [18]. Phylogeny inferences with UPGMA indicated that the two sub-families formed a well supported paraphyletic clade. 
Table 2. Percentage of polymorphism based on RAPD fragments

\begin{tabular}{lllll}
\hline Primers & Total Bands & No. Monomorphics & No. Polymorphics & Plymorphism (\%) \\
\hline OPA3 & 12 & 0 & 12 & 100 \\
OPA4 & 19 & 0 & 19 & 100 \\
OPA5 & 26 & 3 & 23 & 88,46 \\
OPA6 & 19 & 5 & 15 & 78,94 \\
OPA7 & 23 & 3 & 20 & 86,95 \\
OPA8 & 18 & 0 & 18 & 100 \\
OPA9 & 25 & 2 & 23 & 92 \\
OPA10 & 24 & 0 & 24 & 100 \\
OPA11 & 17 & 1 & 16 & 94,11 \\
OAP12 & 23 & 0 & 23 & 100 \\
OPA13 & 22 & 0 & 22 & 100 \\
OPA14 & 16 & 1 & 15 & 93,75 \\
OAP15 & 18 & 3 & 15 & 93,33 \\
OPA16 & 25 & 2 & 23 & 90 \\
OPA17 & 20 & 2 & 18 & 95 \\
OPA18 & 20 & 1 & 19 & 89,28 \\
OAP19 & 28 & 3 & 25 & 84 \\
OPA20 & 19 & 3 & 16 & $\mathbf{9 4 , 3 8}$ \\
\hline Total & $\mathbf{3 7 4}$ & $\mathbf{2 1}$ & $\mathbf{3 5 3}$ & \\
bands & & & &
\end{tabular}

\section{CONCLUSION}

Amaranth family classification based on morphological and molecular data were different. But, in general, both analyses concluded that in there were two sub families in amaranth family. The first sub-family was Amaranthoideae, and the-second sub family was Gomphrenoideae. Each sub family had different members depending on the analyses used. Thus, it is suggested to have a deep analysis employing other molecular markers.

\section{ACKNOWLEDGEMENTS}

This work was supported by I-MHERE program, the specialized research fund for undergraduate program. Thanks to Dr. Ir. Estri Laras Arumingtyas, MSc.St., Ir. Retno Mastuti, MAgSc. DAgSc, Rodliyati Azrianingsih, MSc.Ph.D, and Dr. Sri Rahayu, M.Kes. for reviewing this paper, and Susiati, S.Si for her technical assistance.

\section{REFERENCES}

1. Radford AE (1981) Fundamentals of Plant Systematics. Harper and Rows. New York.

2. Judd WS, CS Campbell, EA Kellog, PF Stevens \& MJ Donoghue (2002) Plant Systematics A Phylogenetic Approach Second Edition. Sinauer Associates. Sunderland.

3. Xu FX \& M Sun (2001) Comparative analysis of phylogenetic relationships of grain amaranths and their wild relatives (Amaranthus; Amaranthaceae) using internal transcribed spacer, amplified fragment length polymorphism, and double-primer fluorescent intersimple sequence repeat markers. Molecular Phylogenetics and Evolution. 21(3): 372-387.

4. Stussey TF (1990) Plant Taxonomy: The Systematic of comparison data. Columbia University Press. New York.

5. Williams JGK, AR Kubelik, KJ Livak, JA Rafalski \& SV Tingey (1990) DNA polymorphisms amplified by arbitrary primers are useful as genetic markers. Nucleic Acids Research. 18: 6531-6535.

6. Mondini L, A Noorani \& M A Pagnotta (2009) Assessing plant genetic diversity by molecular tools. Diversity. 1:19-35.

7. Backer A (1968) Flora of Java Volume I. Walters Noordhoff. Netherland.

8. Sa'ad NS, R Artanti \& T Dewi (2011) Phytoremediation for rehabilitation of agricultural land contaminated by cadmium and copper. Phytoremediation for rehabilitation. 4(1):17-21.

9. Mabry TJ, J Kagan \& H Rossler (1965) Polychemistry. Academic Press. New York.

10. Stafford HA (1994) Anthocyanins and Betalains: Evolution of the Mutually Exclusive Pathways. Plant Science. 101: 91-98.

11. Han XH, ZJ Gao \& XG Xiao (2009) Review Enzymes and Genes Involved in the Betalain Biosynthesis in Higher Plants. African Journal of Biotechnology. 8(24): 6735-6744.

12. Doyle JJ \& JL Doyle (1987) A rapid DNA isolation procedure for small quantities of fresh leaf tissue. Phytochemical Bulletin. 19:11-15.

13. Chawla HS (2003) Plant Biotech: a practical approach. Science Publisher Inc. New Hampshire. 
14. Sneath PHA \& Sokal RR (1973) Numerical Taxonomy. WH Freeman. San Francisco.

15. Rohlf FJ (2000) NTSYS-pc: numerical taxonomy and multivariate analysis system. Exeter Software. Setauket. New York.

16. Kulakow P (1987) Genetics of Grain Amaranths: The Inheritance of Determinance, Panicle Orientation, Dwarfism, and Embryo Color in Amaranthus-Caudatus. Journal of Heredity 78(5): 293-297.

17. Mucjia A \& S Jacobsen (2005) The Genetic Resources of Andean Grain Amaranths (Amaranthus caudatus L., A. Cruentus L. and A. Hipochondriacus L.) in America. FAO-IPGRI Newsletter. 133: 41-44.

18. Kadereit G, T Borsch, K Weising \& H Freitag (2003). Phylogeny of Amaranthaceae and Chenopodiaceae and the evolution of C4 photosynthesis, International Journal of Plant Science. 164(6):959-986. 